\title{
Energy Use and Energy Consumption in Military Camps
}

\author{
Petr DVOŘÁK ${ }^{1}$, Jiř́ ŠTOLLER ${ }^{2}$
}

\begin{abstract}
${ }^{1}$ Department of Engineer Technologies, Faculty of Military Technologies, University of Defence in Brno, Address: Kounicova 65, 66210 Brno, Czech Republic

${ }^{2}$ Department of Engineer Technologies, Faculty of Military Technologies, University of Defence in Brno, Address: Kounicova 65, 66210 Brno, Czech Republic
\end{abstract}

E-mails: p.1petr.dvorak@unob.cz; jiri.stoller@unob.cz

\begin{abstract}
The topic of energy use and energy consumption is currently largely dealt not only in the architecture and civil engineering but also in the military environment. The operating costs of military camps and facilities can be rising extremely quickly especially in hot climate conditions where the requirements for appropriately air-conditioned working places and other mission related areas are crucial for the uninterrupted command and control of any operation. The energy use and energy consumption must be considered already during the planning phase of the military facility and it must take into account as many limiting factors as possible. This is not a completely new problem and many different approaches to the solution are already here and ready to use, and one of them is a method or a system called energy audit that is an efficient tool for improving the energy use and consumption.
\end{abstract}

KEY WORDS: energy use, energy consumption, military camp, energy management system, energy audit, sustainability, environment, resilience

\section{Introduction}

The article deals with the topics of significant energy consumption and low energy effectiveness in the military camps and facilities that are built and operated during field exercises and foreign operations. For a long time now, several NATO countries have been already trying to decrease their strong reliance on fossil fuels and some of them are even considering the zero carbon footprint during their military activities in the near future. There are also several similar activities in progress under different names, for example Green defence, Go green, or Smart energy, and all of them have the same aim, which is to reduce energy consumption and energy costs [1].

The Armed Forces of the Czech Republic are also looking into possible areas where energy of any form could be saved and consumed more effectively with regard to environmental sustainability. The lower the energy consumption, the lower the financial costs, and the logistical burden for deployment of military units. The paper primarily focuses on the possibilities of usage of the methodology of energy audit in the military environment, which is already widely applied in buildings and facilities in the Czech Republic. As an energy management system is an important part of any energy audit, it is also mentioned in the article.

In general, it might be suggested that, the concept of the energy audit is a special kind of energy review, which is specified by the Czech technical standard ČSN EN ISO 50001 Energy Management Systems [2]. According to this technical standard, the energy review is based on the methodology and criteria that should be developed by the organization pursuing better energy use and energy consumption. The document specifies requirements for creation, implementation, and improvement of energy management systems, with the desired outcome to enable any organization to use a systematic approach for the enhancement of energy use and energy consumption. From the methodology point of view, the energy review consists of three basic steps:

1. Analysis of energy use.

2. Identification of major areas of energy consumption.

3. Identification of possible areas for improvement.

In the Czech Republic, the concept of the energy audit was introduced in 2000 by an act No. 406/2000 Coll., on Energy Management, which has been amended on the 25 January 2020 [3]. Furthermore, the numerous paragraphs of the act have been specified by several regulations about energy audit, energy assessment, and energy performance in buildings [4, 5 and 6]. Additionally, some requirements are quantified by related Czech technical standards, especially by a set of documents related to the thermal protection of buildings [7, 8, 9 and 10].

\footnotetext{
${ }^{1}$ Corresponding author. Tel.: 00420-973-443-344.
}

E-mail address: petr.dvorak@unob.cz 


\section{Method of Investigation}

The final report about energy audit of any building or compound must contain at least two options for better energy performance in the examined facility. All suggested options must be thoroughly described from the technical point of view but also their financial impact must be exactly evaluated. In general, there are two possible areas for improvement in any construction or facility regardless of its structure, operation mode, or lifespan, see Table 1. Both areas contain several spots where the enhancement of the building can be done but usually only some of them can be employed at the same time because of different reasons, for example type of the structure or the convenience of the measure.

Table 1.

Areas for improvement in energy performance of the building

\begin{tabular}{|c|c|}
\hline $\begin{array}{c}\text { Structural elements } \\
\text { of the building }\end{array}$ & $\begin{array}{l}\text { Technical systems } \\
\text { inside the building }\end{array}$ \\
\hline - Outside walls & • Lighting \\
\hline - Roofs & - Hot water preparation \\
\hline • Doors & - Electric devices \\
\hline - Windows & - Measurement and regulation \\
\hline - Interior structures between spaces with different temperature & - Heating, ventilation and air conditioning \\
\hline
\end{tabular}

The measures in the first area (structural elements of the building) need high investment and they are not suitable for the military environment because planning and acquisition are long-term processes, which would not deliver energy savings in the short time period. The second area (technical systems inside the building) offers more low-cost opportunities, for example to replace old electric devices or to introduce energy management system in the building. The final report about energy audit, which is a cornerstone for any energy performance improvements, consists of several parts that create the whole system and none of them can be avoided [4]:

1. Title page.

2. Identification data.

3. Description of the current state of the building.

4. Evaluation of the current state of the building.

5. List of measures to improve energy efficiency.

6. Options (two at least) from the list of measures to improve energy efficiency.

7. Selection of the best-suited option.

8. Final recommendations.

9. Energy audit record sheet.

10. Certificate of the author of energy audit.

In the annexes to the [4], there are several tables and charts that helps to cover all areas of energy use and energy consumption in the examined facility. The tables do not only quantify the individual items in the units of energy but they also enumerate costs and expenses for each source of energy. The financial evaluation of the options is carried out, and the main decision criterion for the selection of the best option is the net present value criterion. In addition, there are two other supplementary criteria for better description of the chosen option - the internal rate of return and the real payback time.

The final report about energy audit goes even further into the details [4], as it requires each option to be evaluated from the environmental point of view. In this case, it means that the amount of emissions of several pollutants must be calculated: solid pollutants and specifically atmospheric aerosol particles also known as particulate matter (PM10 and PM2.5), volatile organic compounds, sulphur dioxide, carbon dioxide, nitrogen oxides, and ammonia. This ecological assessment should prove the direct impact of measures on the air quality but it is extremely difficult both to assess precisely the current state of air and its improvement after the measures are implemented.

\section{Investigation Results}

The good use of the energy management system of any form within military facilities can made the handover and takeover procedures between the military units easier and faster because all energy related processes would be well documented and recorded. Moreover, the Allied Tactical Publication (ATP) called Deployed Force Infrastructure, 
which was promulgated by the Standardization Agreement STANAG 2632 in 2018, also recommends it, and it emphasizes that such approach can not only bring energy savings but most importantly the free resources can be used for mission related activities [11, 12].

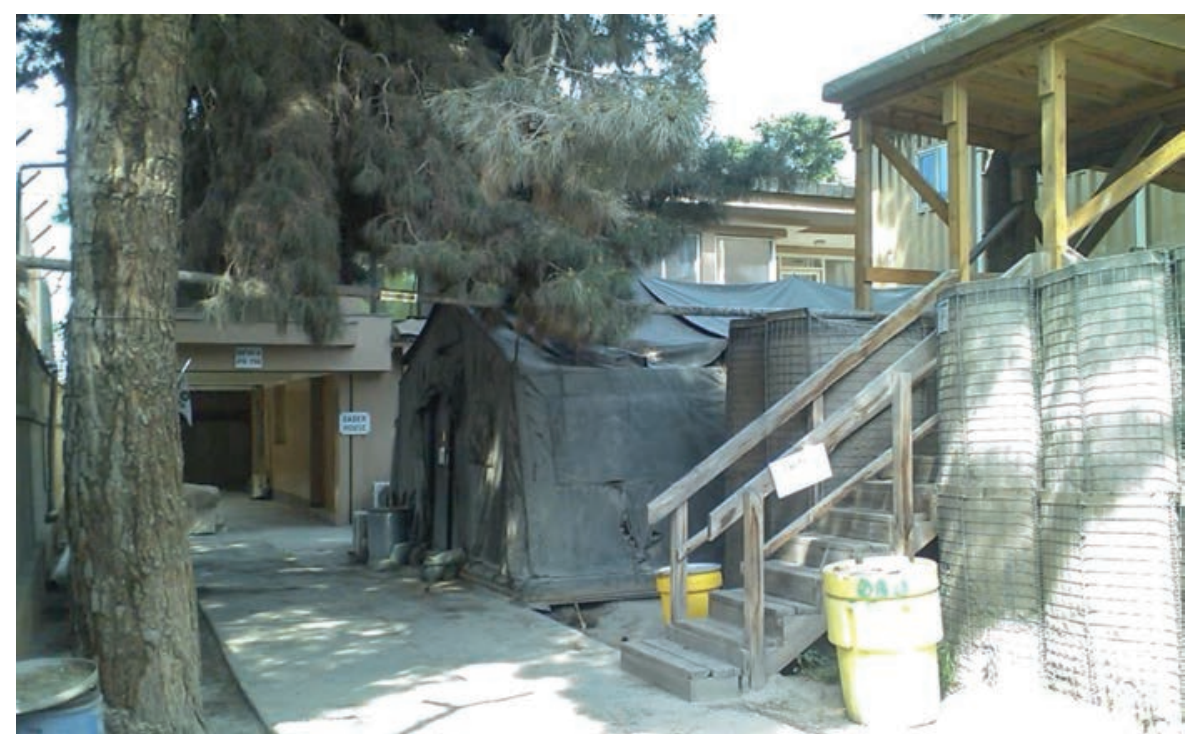

Fig. 1. Transient accommodation in a tent, military camp in Kabul. Source: author

Currently, the technical term of resilience can best describe NATO's aim regarding energy efficiency. Military planners can enhance resilience by considering energy management issues and design the deployed force infrastructure to be more efficiently powered and managed. This will undoubtedly result in a smaller logistical burden and lower requirements for the protection of units for logistical convoys, which are used to sustain the military camps. It will also give commanders greater flexibility while providing soldiers with no reduced quality of life [11].

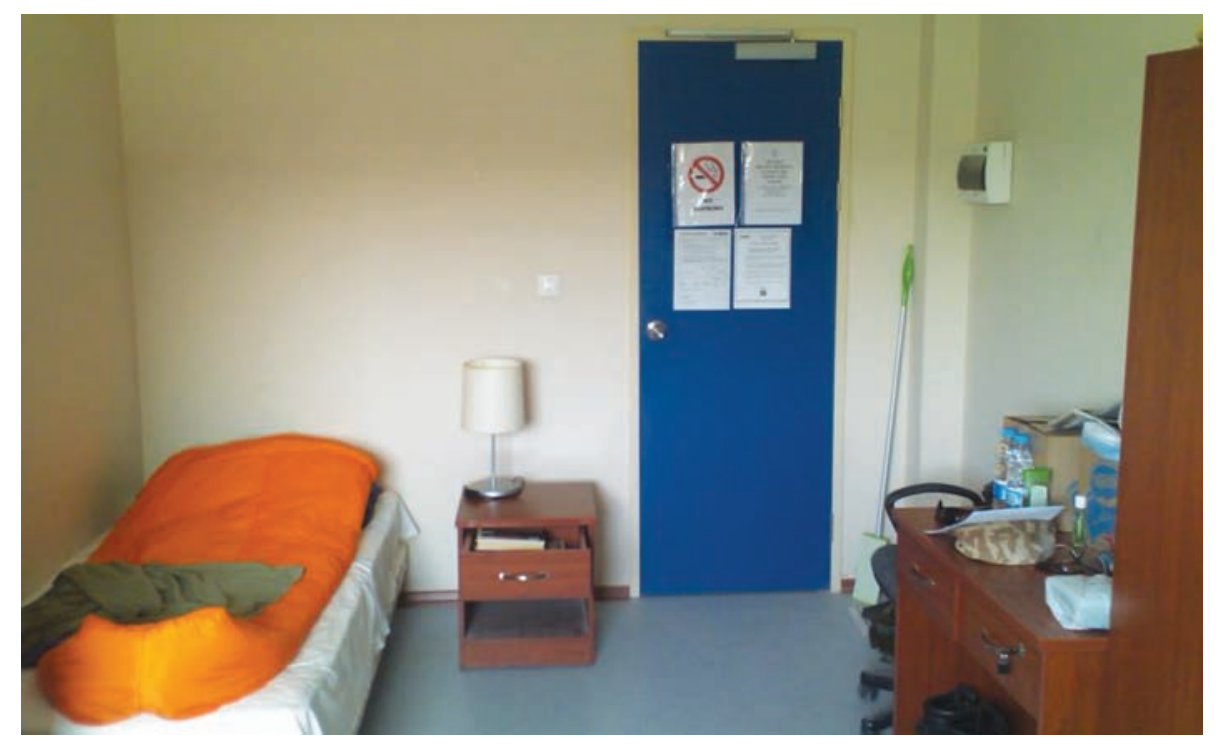

Fig. 2. Permanent accommodation in a building, military base at Kandahar Airfield. Source: author

In different military camps and compounds, very diverse building structures and arrangements can be found. On the one hand, there are simple structures, for example, shelters, sheds or tents, and on the other hand, semipermanent structures, and in some rare cases even permanent structures can be found, see Fig. 1 and Fig. 2. Because of these reasons, it is not always possible to use all energy improvement measures as shown in the Table 1 for all buildings, and it is necessary to adjust the set of energy improving measures for the specific location and time. 


\section{Conclusions}

The problems of energy use and energy consumption in military camps and facilities are a critical part of a long-term commitment to environmental protection and sustainability during any NATO exercise and operation within its own territory but especially in a foreign country. Moreover, it is also a kind of strong obligation to the host nations to use their land and its natural resources highly responsibly. The early implementation of any energy management system in the military environment could undoubtedly result in a significant decrease of operation expenses and costs, and in a smaller environmental footprint of the military presence in any geographical area and regardless of the duration of the deployment of the military unit.

Furthermore, it is crucial to mention that saving energy is not a one-time step but an ongoing activity through the lifespan of the building structure and the whole military facility. As it is stated in [2], the energy saving is a repeated cycle of everyday practices that can be divided into four interconnected groups: Plan, Do, Check, and Act. This cycle is built on the continual improvement following from the data analysis of measurement and regulation that is subsequently reflected in the enhancement of the energy planning and the energy policy. The success of energy saving depends on everybody's behaviour and all working levels must be committed to the improvement of energy performance, especially leaders and commanders.

\section{Acknowledgements}

The work presented in this article has been supported by the Ministry of Defence of the Czech Republic through the Department 201 research program "Development of technologies in weapons construction, ammunition, weapons instrumentation, materials science and military infrastructure 2016-2020" at the University of Defence in Brno, Faculty of Military Technology, Czech Republic.

\section{References}

1. Smart Energy Team Comprehensive Report. NATO Science for Peace and Security Programme. May 2015,64 p. [online cit.: 2020-01-30]. Available from http://www.natolibguides.info/ld.php?content_id=18110194.

2. Czech Technical Standard ČSN EN ISO 50001 Energy management systems - Requirements with guidance for use. Czech Office for Standards, Metrology and Testing. April 2019, 52 p. (in Czech).

3. Act No. 406/2000 Coll., on Energy Management. Ministry of Industry and Trade of the Czech Republic. Amended on 2020-01-25, 48 p. (in Czech).

4. Regulation No. 480/2012 Coll., on Energy Audit and Energy Assessment. Czech Republic Ministry of Industry and Trade. Amended on 2016-10-11, 13 p. (in Czech).

5. Regulation No. 78/2013 Coll., on Energy Performance in Buildings. Czech Republic Ministry of Industry and Trade. Amended on 2015-12-01, 11 p. (in Czech).

6. Regulation No. 4/2020 Coll., on Energy Specialists. Czech Republic Ministry of Industry and Trade. Amended on 2020-01-25, 9 p. (in Czech).

7. Czech Technical Standard ČSN 73 0540-1: Thermal protection of buildings - Part 1: Terminology. Czech Office for Standards, Metrology and Testing. July 2005, 68 p. (in Czech).

8. Czech Technical Standard ČSN 73 0540-2 Thermal protection of buildings - Part 2: Requirements. Czech Office for Standards, Metrology and Testing. April 2012, 56 p. (in Czech).

9. Czech Technical Standard ČSN 73 0540-3 Thermal protection of buildings - Part 3: Design value quantities. Czech Office for Standards, Metrology and Testing. December 2005, 96 p. (in Czech).

10. Czech Technical Standard ČSN 73 0540-4 Thermal protection of buildings - Part 4: Calculation methods. Czech Office for Standards, Metrology and Testing. July 2005, 60 p. (in Czech).

11. Allied Tactical Publication ATP-3.12.1.4 Deployed Force Infrastructure, Edition A, version 1. NATO Standardization Office. August 2018, 121 p.

12. Standardization Agreement STANAG 2632 Deployed Force Infrastructure, Edition 1. NATO Standardization Office. August 2018, 7 p. 